\title{
Assessment of Intestinal Parasites of Commercial Layers in Selected Local Government Areas of Rivers State, Nigeria and Their Public Health Implications
}

\author{
Wokem GN ${ }^{1 *}$ and Obiyor $\mathrm{ET}^{2}$ \\ ${ }^{1}$ Department of Medical Laboratory Sciences, Rivers State University, Nigeria \\ ${ }^{2}$ Department of Animal and Environmental Biology, University of Port Harcourt, Nigeria
}

Submission: December 11, 2017; Published: February 02, 2018

*Corresponding author: Wokem GN, Department of Medical Laboratory Sciences, Faculty of Science, Rivers State University, Nkpolu Oroworukwo, Port Harcourt, Nigeria, Email: g.ndrwokem@yahoo.com

\begin{abstract}
The study was carried out from April to July 2016 in selected Local Government Areas of Rivers State; Ikwerre, Emohua, Etche, Ahoada and Obio/Akpo LGAs. The aim was to assess the presence of intestinal parasites in commercial layers and to relate the findings to their public health importance. Two hundred birds' faecal samples were randomly collected from the selected farms and analyzed using salt saturation floatation technique. Out of 200 faecal samples examined, 130 (65\%) samples were infected with Ascaridia galli 39(30\%), Eimeria species 54(41.5\%), Heterakis gallinarum 13(10\%), Capillaria spp 3(2.3\%) and Trychostrongylus spp 16(12.3). Mixed infection were observed in 34(26.1\%) samples consisting of A. galli + Eimeria spp + H. gallinarum, Eimeria species + Heterakis gallinarum + Trychstrongylus species, Eimeria species + Ascaridia galli + Heterakis gallinarum + Trychstrongylus species. The prevalence rates from each of the LGAs were 75\%, 45\%, 70\%, 55\% and $80 \%$ respectively. There was no statistical significant different observed in the different LGAs $(\mathrm{P}>0.05)$ but Obio/Akpo recorded slightly higher prevalence than other LGAs $(\mathrm{P}<0.05)$. Age groups were categorized in weeks with their infection prevalence rates 1-5 $(37 \%), 6-10(70 \%), 11-15(60 \%)$ and 16 20 weeks (85\%). There was high significant difference between the age groups. $\left(\mathrm{Ch}^{2}=20.935, \mathrm{P}=0.000\right)$. Well constructed questionnaire were used to evaluate poultry farmers management practices in their farms, information extracted showed that most of the farms were having poor ventilation, overcrowding of birds, water spillage, poor hygienic practices and negligence by farmers to treat their birds at the right stage. It was concluded that reduction in production and reproduction potentials in poultry farms have adverse effects on the quality and quantity of protein available for public consumption.
\end{abstract}

Keywords: Intestinal parasites; Commercial layers; Rivers state

\section{Introduction}

In Nigeria, poultry is divided into two sectors, commercialized and the village enterprise popularly known as free range. Commercial poultry farmers are the major producers of poultry products in large quantities with specialized equipments and management approach Agbolade et al. [1].

On estimate, poultry industry contributes about $88.6 \%$ of all meat consumed in the world and thereby constitute a major food and protein sources [2]. In Africa, Nigeria rates very high in poultry farming and consumption of poultry products; unrestricted by any religion or culture. Apart from well known factors like avian influenza, new castle diseases and a few others that cause constrains in the production of poultry products in Nigeria, Rivers State inclusive; parasitism is a major factor that threatens poultry farming. Parasitic diseases have significantly interfered with poultry productivity and commercial farming. It reduces the economic income and in turn negatively affects the development of the industry. Intestinal parasites of poultry are common in this part of the country because of the favorable climatic conditions for their development and also poor management practices among farmers due to poverty.

Helminthes and protozoans are the major intestinal parasites that affect poultry farming. Ascaridia galli, Heterakis gallinarum, Capillaria species and Raillietina species are all helminthes. Coccidian is a class of Protozoa that causes a well known disease referred to as coccidiosis. It is caused by different Eimeria species. Losses due to reduced productivity such as poor weight gain, poor egg production and rate of mortality caused by parasitic protozoans and helminthes are economically very important to the poultry industry. The parasites have serious impact on poultry health, productivity, quality and quantity of products as reported by Aman et al., (2013). Considering the public health significance of chicken, its economic values, nutritional and social importance in the globe and in Nigeria in particular, the relevance of this study cannot be over emphasized. It is an assumed fact that parasitic diseases infest both exotic and 
local breeds of domestic birds reducing optimum productivity in layers. This assumption has geared many researchers into understanding the mode of parasitic infestation towards formulation of control and eradication strategies. Results from such research include those of Luka \& Ndams [3], Matur et al. [4], Hadipour et al. [5], and Okafor-Elenwo \& Elenwo [6]. This study is aimed at assessing the presence of intestinal parasites of commercial Layers and relating the findings to their public health importance.

\section{Materials and Methods}

\section{Study areas}

The study was carried out in Ikwerre, Obio/Akpo, Emohua, Ahoada and Etche Local Government Areas in Rivers State, Nigeria. Climatic conditions are typical of the rainforest ecological zone. Each of the LGAs selected has its latitude and longitude. Ikwerre has a total area of $1,380 \mathrm{KM}^{2}$. It lies at latitude $4^{\circ} 54^{\prime} 280 \mathrm{~N}$ and longitude $6^{\circ} 53^{\prime} 2.62^{\prime} \mathrm{E}$, Obio/Akpo has a total area of $260 \mathrm{KM} 2$ and lies at latitude $4^{\circ} 45 \mathrm{~N}$ and longitude $6^{\circ} 51.00$ $\mathrm{E}$; Etche is at latitude $4^{\circ} 58^{\prime} 37.00 \mathrm{~N}$ and longitude $7^{\circ} \mathrm{o} 3^{\prime} 1700 \mathrm{E}$, Emuoha lies at latitude $4^{\circ} .88 \mathrm{~N}$ and longitude $6^{\circ} 87.26 \mathrm{E}$ while Ahoada lies at latitude $6^{\circ} 87.26 \mathrm{~N}$ and longitude $6^{\circ} 38^{\prime} 59.9^{\prime \prime} \mathrm{E}$. The LGAs randomly selected were those in agreement with the criteria set for selection.

\section{Sample Collection and Analysis}

The study involved weekly collection of faecal samples for a period of three months, from April to July 2016. Prior to faecal sample collection, poultry farm owners' permission was solicited using an introductory letter from the Department of Animal and Environmental Department, University of Port Harcourt, Nigeria and only those farmers who consented to the request had their farms included for the study.

A total of two hundred (200) faecal samples were collected from commercial layers. The age of the birds were grouped in weeks. Data were collected using a well structured questionnaire, observations and interviews from the twenty-five selected poultry farmers who responded to the study. Freshly voided

Table 2: Prevalence of intestinal parasites in relation to age of the layers Chicken.

\begin{tabular}{|c|c|c|c|c|c|c|}
\hline Breed & Age (weeks) & No. of samples Examined & No. of Positive Sample & Prevalence (\%) & $\mathrm{Ch}^{2}$ & P-Value \\
\hline \multirow{4}{*}{ Layers } & 5-Jan & 80 & 30 & 17 & 20.935 & 0 \\
\hline & 10-Jun & 40 & 28 & 70 & & \\
\hline & $15-$ Nov & 20 & 12 & 60 & & \\
\hline & $16-20$ & 20 & 17 & 85 & & \\
\hline
\end{tabular}

Table 3: Parasites recovered from layers faecal samples in the LGAs.

\begin{tabular}{|c|c|c|c|c|c|c|}
\hline LGAs/Parasites & Ascaridia galli & Eimeria spp & Heterakis gallinarum & Trychostrongylus spp & Capillaria spp & Unknown spp \\
\hline Ikwerre & 10 & 11 & 1 & 1 & - & - \\
\hline Emohua & 4 & 9 & 1 & - & 2 & 3 \\
\hline Etche & 9 & 6 & 4 & 3 & - & - \\
\hline Obio/Akpo & 9 & 8 & 5 & 7 & 1 & 2 \\
\hline Ahoada & 7 & 10 & 2 & 5 & - & - \\
\hline
\end{tabular}


Out of a total of 200 faecal samples examined in five LGAS, $130(65 \%)$ faecal samples were infested as shown in Table 1. Obio/ Akpo recorded the highest prevalence $80 \%$. Intestinal parasites prevalence from each of the LGAs were 75\%, 45\%, 70\%, 55\% and $80 \%$ respectively. There was a higher statistical significant difference observed in the highest $(80 \%)$ and least (45\%) prevalence rates in the LGAs $(\mathrm{P}<0.05)$. Table 2 , shows that layers of week 1 -5 had the list prevalence (17\%) while 16- 20 weeks old had the highest $(85 \%)$ which is statistically significant $(\mathrm{P}<$ 0.05). Table 3, shows the parasites recovered as thus: Ascaridia galli 39(30\%), Eimeria species 54(41.5\%), Heterakis gallinarum 13(10\%), Capillaria spp 3(2.3\%) and Trychostrongylus spp 16(12.3). Mixed infection were observed in 34(26.1\%) samples which were A.galli + Eimeria spp + H. gallinarum, Eimeria species + Heterakis gallinarum + Trychstrongylus species + Eimeria species + Ascaridia galli + Heterakis gallinarum + Trychstrongylus

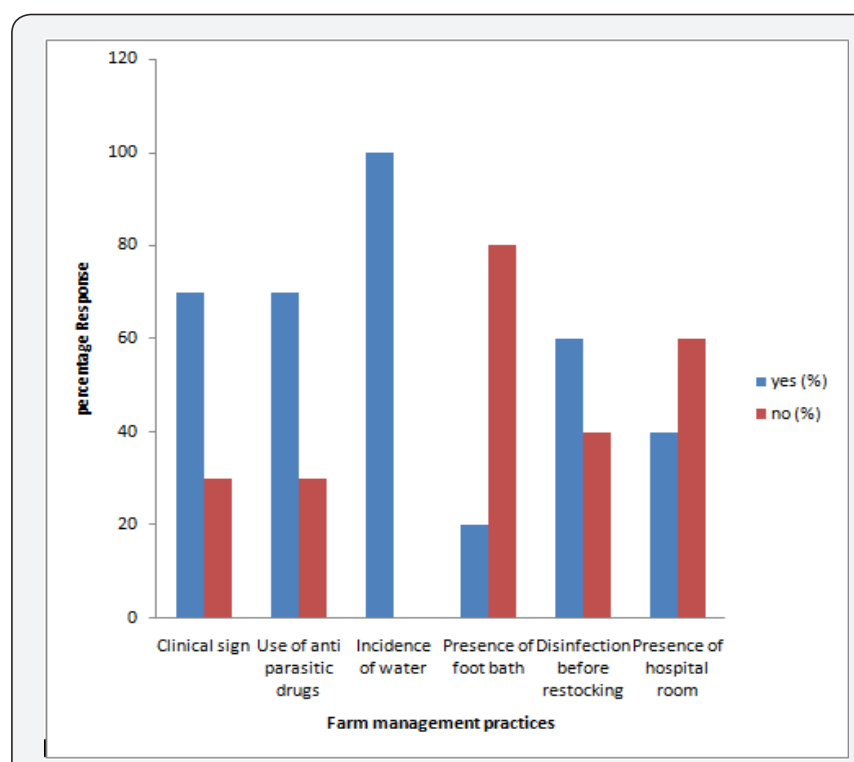

Figure 1a: Farmers management practices seen as risk factors.

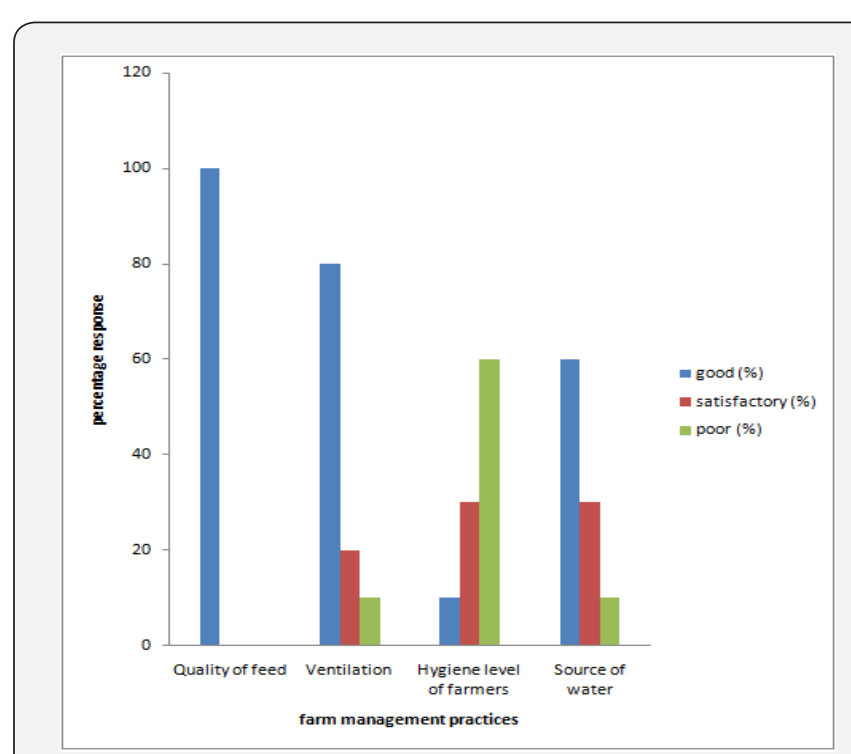

Figure 1b: Farmers management practices seen as risk factors. species. In Figures 1a \& 1b below, of a total of twenty-five filled questionnaires retrieved from the farmers, incidence of water spillage was $100 \%$. The presence of foot bath at the entrance of the poultry rooms were observed in only $20 \%$ of the farms. Also, $60 \%$ of the farmers have separate rooms for their sick birds and $60 \%$ only disinfect their poultry rooms before restocking. Although, $100 \%$ of the farmers use quality feeds for their birds, good ventilation was observed in $80 \%$ of the farms while hygienic level was poor in $60 \%$. Farmers who use good water sources were $60 \%$. Figure 2 indicates that only $20 \%$ of the farmers dispose their litters once in two weeks, $30 \%$ dispose theirs once per batch and $50 \%$ dispose once in a month. Figure 3 , indicates that $80 \%$ of the farmers purchase their birds at a day old from different large farms like Zartech, Chimero, Obasanjo and Niger chicks Companies and only $20 \%$ of the farmers purchase $2-4$ weeks old bird from other retailers.

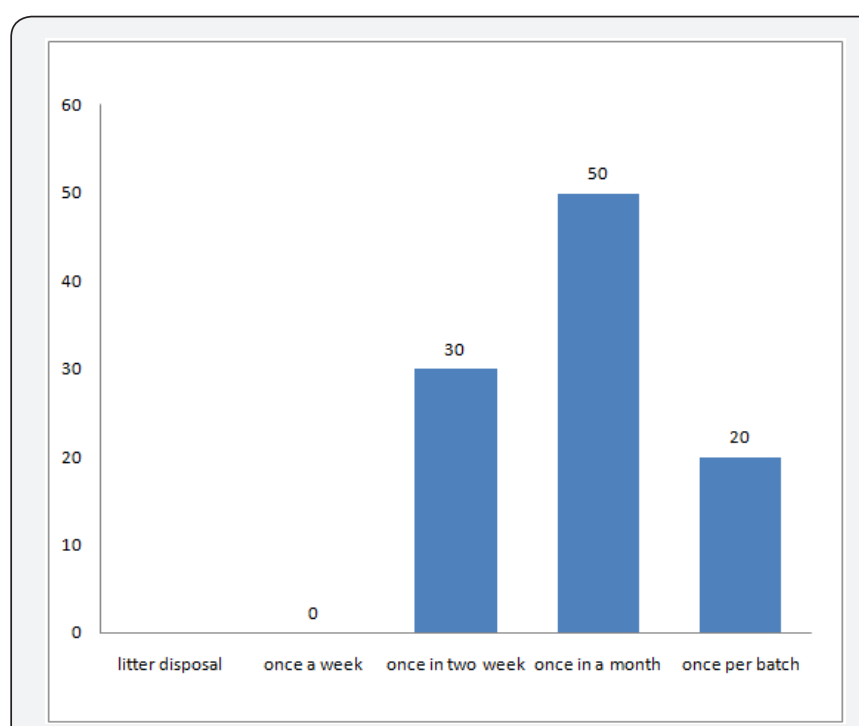

Figure 2: Percentage frequency of litter disposal by poultry farmers.

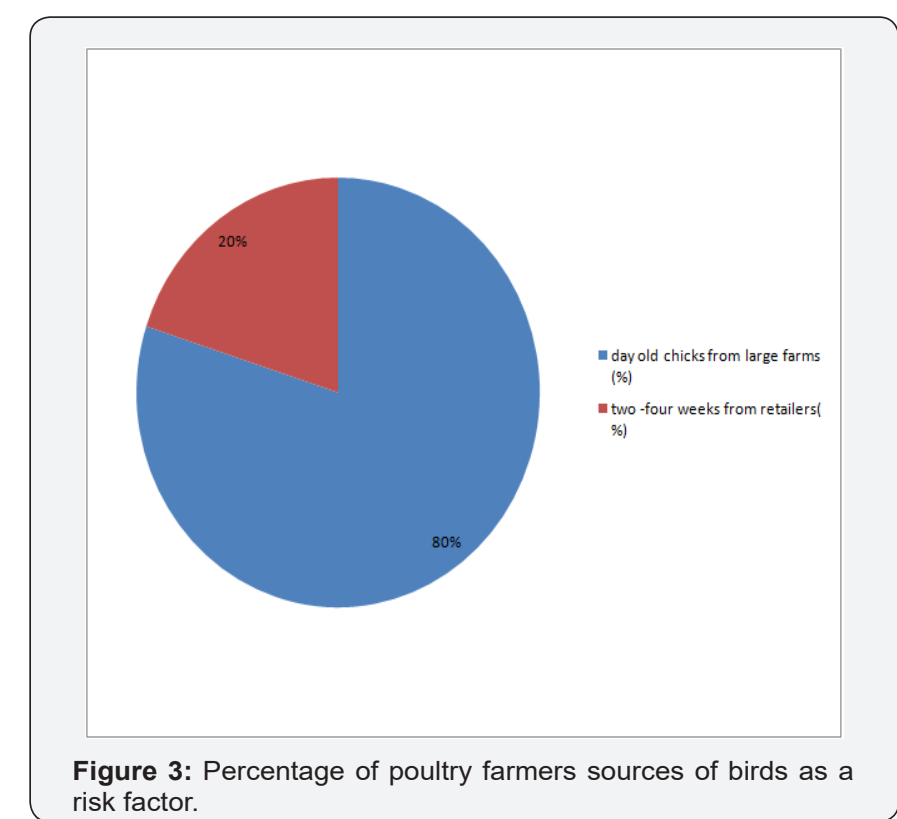




\section{Discussion}

Out of 200 layers' breed faecal samples collected, 130(65\%) were positive for intestinal parasites; parasites discovered were Eimeria species 54(41.5\%), Ascaridia galli 39(30\%) samples and mixed infection 39(34.3\%). In layers breed; Eimeria species were found in more samples than A. galli. The result of this study is in agreement with Salam, [9], Agishi, et al. [10], who made similar observations in their work on intestinal parasites of Chicken. The high parasitic prevalence observed may be attributed to poor management practices observed in some of the poultry farms in the study areas. The older litters were not removed and replaced with new dry wood shaving or saw dust very often; thereby making the poultry room floor wet and cake which in conducive for these parasites to thrive. Again water spillage, leakages from the roof of the poultry house, and the wet litters served as favourable environment for the parasites to incubate as also observed by Kolade et al. [11] and Elenwo et al. [12]. Moreover, the high prevalence rate of Eimeria oocyst in the faecal samples may be due to poor management in the poultry house hence coccidial oocyst were always present and spread very easily in a poor managed poultry house especially when left humid with caked litters as stated by Bachaya et al. [13]. Mixed infections of two or more species of parasites per faecal sample collected was very common in the study areas, and this has also been recorded by other scientists like Heyradin et al. [14], Ohaeri \& Okwum [15] and Junaidu et al. [16] in their studies.

Parasitic burden were more in birds of 16-20 weeks old. The higher prevalence in the older birds may be due to decreased immunity in the older chicken. It may also be attributed to farmers' negligence in treating their birds at the right stage which later manifested on the birds at older age when they could no longer be treated with antibiotics and anti-helminthic agents, hence this may delay or stop entirely their egg laying period or reproductive potentials and so reduce the quantity of protein made available for public consumption. Another possible reason is that, the layers eating habit is increased at their older stage which may likely expose them to picking indiscriminately resulting to more infection from contaminated feeds, as contributed by poultry farmers.

\section{Conclusion}

In conclusion, the findings of the study have shown that intestinal parasites are highly prevalent in commercial layers in the studied LGAs in Rivers State, Nigeria. There are high levels of poor management practices, poor skills and negligence among the farmers which expose the layer breed of birds to these prevailing parasites. The poultry farmers are therefore encouraged to take appropriate measures in the control of intestinal parasitic diseases in Rivers State by administering anthelminthic agents at the right stage. Improved management skills and good farming practices may be cost effective as well as increase poultry production potentials.

\section{Acknowledgement}

The authors appreciate the owners of the poultry farms in Ikweerre, Obio/Akpo, Emohua, Ahoada and Etche LGAs, Rivers State, Nigeria, for their understanding and support during the study.

\section{References}

1. Agbolade OM, Arosoye AS, Akajiugo EC, Akinyemi AA, Ariba O, et al. (2014) Gastrointestinal parasite of domestic fowl from Ijebu North, Southwestern Nigeria. BRJ 3(7): 60-64.

2. Singh RG, Seepersad (2001) A profile of the broiler industry in Trinidad and Tobago in the Caribbean poultry. Public Caribbean Poultry Association, pp 20.

3. Luka SA, Ndams IS (2007) Gastrointestinal parasites of domestic chicken Gallus domesticus in Samaru Zaria, Nigeria. Science World Journal 2(1): 27-29.

4. Matur BM, Dawan NN, Malann YD (2010) Gastrointestinal helminth parasites of local and exotic chickens slaughtered in Gwagwalada, Abuja, Nigeria. New York science Journal 3(5): 96-99.

5. Hadipour MM, Olaiyaie A, Naderi M, Azad F, Nekoule O, et al. (2011) Prevalence of Eimeria species in scavenging native chicken of Shiraz, Iran. African Journal Microbiology Research 5(20): 3295-3299.

6. Okafor Elenwo EJ, Elenwo AC (2014) Co-infection of helminthes and protozoan parasites in intestinal tract of the domestic fowl Gallus domesticus in parts of Nigeria. International Journal of Pharmacological Research, Biological Science 3: 440-449.

7. Urquhart GM, Armour DJI, Duna AM, Jennings FW (1987) Veterinary parasitology London. Longman group ltd., UK, pp. 150.

8. Monica C (2005) District laboratory practice in tropical country. $\left(2^{\text {nd }}\right.$ edn). Part 1, p. 97.

9. Salam ST (2015) Ascariasis in backyard chicken prevalence, pathology and control. International journal of Recent Scientific Research 6(4): 3361-3365.

10. Agishi GI, Luga I, Rabo JS (2016) Prevalence of coccidiosis and Eimeria species in layers and broilers at slaughter houses in Makurdi, Benue state. The IJES 5(2): 08-11.

11. Kolade O, Agbolade E, Olufemi M (2014) Inetestinal parasites of local and exotic domestic fowls in Owoyele, Yewa North, Ogun state, Nigeria. Journal of Agricultural and soil science 2(1): 082-085.

12. Elenwo AC, Okafor EEJ (2014) Co-infection of helminthes and protozoan parasites in intestinal tract of domestic fowl in parts of Nigeria. International Journal of Pharmacological Research 3: 1-5.

13. Bachaya HA, Raza MA, Khan MN, Iqbal Z, Abbas RZ, et al. (2012) Predominanace and detection of different Eimeria species causing coccidiosis in layer chickens. Journal of Animal and Plant Science 22(3): 597-600.

14. Heyradin H, Hassen C, Yosef D, Molalegne B (2012) Gastrointestinal helminths are highly prevalent in scavenging chicken of selected districts of eastern shewa zone, Ethiopia. Pak J Biol Sci 15(6): 284-289.

15. Ohari CC, Okwum C (2013) Helminth parasites of domestic fowls in Ikwuano, Abia state, Nigeria. Journal of Natural Sciences Research 3(11): 1-6.

16. Junaidu HI, Luka SA, Myinyawa A (2014) Prevalence of gastrointestinal helminth parasites of domestic fowl (Gallus-gallus domesticus) slaughtered in Giwa market local government area. Journal of Natural Sciences Research 19(4). 
Your next submission with Juniper Publishers will reach you the below assets

- Quality Editorial service

- Swift Peer Review

- Reprints availability

- E-prints Service

- Manuscript Podcast for convenient understanding

- Global attainment for your research

- Manuscript accessibility in different formats (Pdf, E-pub, Full Text, Audio)

- Unceasing customer service

Track the below URL for one-step submission https://juniperpublishers.com/online-submission.php 